\title{
Bar deposition in glacial outburst floods: scaling, post-flood reworking, and implications for the geomorphological and sedimentary record
}

\section{Formation de bancs lors des jökulhlaups d'éruption sous- glaciaire : invariance d'échelle, remaniement post-crue et implications pour l'enregistrement géomorphologique et sédimentaire}

\author{
Philip M. Marren*a \\ ${ }^{a}$ Department of Geography and International Development - University of Chester - Chester, UK. \\ *Auteur correspondant. Tél : +44 1244511408 \\ Courriel : p.marren@chester.ac.uk (P. Marren)
}

\begin{abstract}
The appearance of a flood deposit in the geomorphological and sedimentary record is a product of the both the processes operating during the flood, and those that occur afterwards and overprinting the deposit with a record of 'normal' processes. Nearly half of the total discharge of the November 1996 jökulhlaup on Skeiðarársandur was discharged through the Skeiðará river. The flood deposits have been extensively reworked since, up until 2009 when the channel was abandoned, effectively leaving the Skeiðará as a terrace, when retreat of Skeiðarárjökull directed meltwater to the adjacent Gígjukvísl river system. This paper describes the creation and modification of jökulhlaup barforms in the Skeiðará river, relating the changes to post-flood fluvial processes and glacier retreat. Large compound bars formed from the amalgamation of unit bars up to $1.5 \mathrm{~km}$ long. The location of the compound bars was governed by the macro-scale topography of the flood channel, and their size by upstream channel width in accordance with bar-scaling theory. Jökulhlaup bars are therefore scale invariant and formed in a similar fashion to braid bars in non-jökulhlaup braided rivers. Post-flood fragmentation and reworking of the bars consistently increased the length-width ratio of preserved bar fragments from approximately two and one half to over five. These observations increase our understanding of the preservation potential and final form of jökulhlaup deposits and provide the basis for an improved model for the recognition of jökulhlaup deposits in the geomorphological and sedimentary record.
\end{abstract}

Key words: Iceland, braided river, jökulhlaup, sandur, proglacial, fluvial, scale invariance

\begin{abstract}
Résumé
L'apparition d'un dépôt de crue dans l'enregistrement géomorphologique et sédimentaire est à la fois le produit des processus qui fonctionnent lors de la crue, mais également de ceux opérant après l'événement. Ces derniers remanient le dépôt de crue et surimposent à l'archive sédimentaire un enregistrement géomorphologique de processus fluviaux 'normaux'. Près de la moitié du volume d'eau total engendré par le jökulhlaup du Skeiðarársandur de novembre 1996 a été évacué par la rivière Skeiðará. Depuis, les dépôts de crue ont été largement remanié. En 2009, le recul glaciaire du Skeiðarárjökull a provoqué la capture du chenal de crue de la Skeiðará par la rivière voisine de Gígjukvísl, formant ainsi une terrasse préservant les formes fluviales. Ce document décrit la formation et la modification de la morphologie des bancs de jökulhlaup dans la rivière Skeiðará par les remaniements fluviaux post-crue et le recul glaciaire. Les grands bancs composites ont été formés à partir de la fusion de bancs unitaires jusqu'à $1,5 \mathrm{~km}$ de long. La localisation des bancs composites est commandée par la macro-topographie du chenal de crue. Leur taille dépend de la largeur du chenal en amont conformément à la «bar-scaling theory ». Ainsi, les bancs de jökulhlaup présentent une invariance d'échelle et sont formés de la même manière que les bancs des cours d'eau en tresses non-affectés par les jökulhlaups. La fragmentation post-crue et le remaniement des bancs a invariablement augmenté le rapport longueur/largeur des fragments conservés des bancs de deux et demi à plus de cinq. Ces observations complètent notre compréhension du potentiel de préservation et de morphologie finale des dépôts de Jökulhlaup. Elles contribuent également à poser les bases d'un modèle amélioré pour la reconnaissance des dépôts de jökulhlaup dans les enregistrements géomorphologiques et sédimentaires.
\end{abstract}

Mots clés: Islande, cours d'eau en tresses, jökulhlaup, sandur, proglaciaire, fluvial, invariance d'échelle

Version française abrégée 
L'apparition d'un dépôt de crue dans l'enregistrement géomorphologique et sédimentaire est un produit des processus qui fonctionnaient lors de la crue, y compris le pic de crue et la décrue, couplés aux processus opérant après l'événement. Parmi les jökulhlaups récents qui ont eu lieu en Islande, le plus grand et le plus spectaculaire fut le jökulhlaup de novembre 1996 (Russell et Knudsen, 1999). La rivière Skeiðará fut affecté par d'importants dépôts et la formation de bancs à l'intérieur du chenal de crue. Ce dernier fut d'ailleurs le principal chenal d'évacuation de la plupart des grands jökulhlaups précédents. Jusqu'à l'événement de 1996, il n'avait pas enregistré de grands changements morphologiques (Marren et Schuh, 2009).

Après le jökulhlaup de 1996, l'incision du chenal de la Skeiðará est restée très faible, entre 1996 et 2001, bien que la remobilisation latérale des dépôts de jökulhlaup soit effective durant cette période (Smith et al., 2006 ; Marren et al., 2002 ; Marren et Schuh, 2009). Cette étude utilise les bancs de la Skeiðará comme base pour examiner la morphologie des bancs de jökulhlaup remaniés et tirer de nouvelles conclusions sur : (1) les critères pour identifier l'occurrence de jökulhlaups dans les enregistrements géomorphologiques et (2) la relation entre les dépôts de crue et les dépôts fluviaux communs dans les paysages marginaux. Près de la sortie du glacier, le drainage de la crue de 1996 s'est divisé autour d'un fragment de la moraine en deux branches qui sont habituellement désignées comme la Skeiðará occidentale et la Skeiðará orientale (Russell et Knudsen, 1999). Un grand banc s'est formé à la confluence des deux branches de la Skeiðará (marqué comme 'A' sur la fig. 3). Dans le chenal principal de la Skeiðará, les sédiments ont été transportés sous forme de bancs en losange d'environ 1000 à $1500 \mathrm{~m}$ de long avec des fronts lobés. Les grands bancs composites se forment lorsque les bancs commencent à fusionner. Le banc composite le plus en amont s'est développé dans la section du chenal de la Skeiðará orientale située en aval de l'ouvrage de protection de Skaftafell. Initialement de forme très allongé, le banc médian a progressivement évolué en banc composite plus complexe durant la crue (marqué comme ' $B$ ' sur la fig. 3).

Une seconde zone de dépôt s'est formée sur le côté ouest du chenal. Sur la photographie aérienne de la crue de 1996, cette zone est globalement submergée même si de nombreux blocs de glace déposés sur les crêtes des bancs sont visibles. Ce banc occupe environ un tiers de la largeur du chenal, l'espace restant étant occupé par des eaux plus rapides et profondes (marqué comme ' $C$ ' sur la fig. 3). La photographie post-crue de 1997 montre la zone de dépôt s'étendant sur les deux tiers de la largeur du chenal. Le secteur au centre du chenal s'est vraisemblablement formé tardivement lors de la crue et fut plus profondément ré-incisé lors de la décrue (marqué comme 'D' sur la fig. 3). Généralement, la surface d'un banc de jökulhlaup est clairement identifiable par la présence de nombreuses marques laissées par les blocs de glace transportés et déposés lors de la crue. La phase de décrue du jökulhlaup de 1996 et les remaniements ont incisé le banc et l'ont divisé en sous-bancs qui ont constitué le point de départ du remaniement postérieur. En 2001, les dépôts du jökulhlaup de 1996 dans le chenal de la Skeiðará étaient 2,5 à 3 m plus hauts que la surface des bancs remaniés adjacents (Marren et al., 2002).

La remobilisation des dépôts du jökulhlaup de 1996 a commencé au cours de la saison d'ablation de 1997. Les photographies aériennes de 1997, 2003 et 2012 témoignent de l'ampleur des changements du chenal au cours de la période de réajustement post-jökulhlaup. A l'intérieur du chenal principal de la Skeiðará, toutes les traces de la crue de 1996 ont rapidement été effacées. Le remaniement latéral des bancs a progressivement réduit leur superficie même si aucune crue n'a été en mesure de détruire la totalité des traces à la surface des bancs du jökulhlaup de 1996 (fig. 4). Dans le secteur oriental et proximal, les bancs de la Skeiðará ont été précocement remaniés, surtout avant 2003. La zone distale du banc $B$ a été réduite mais les fragments remaniés ont néanmoins conservé la forme globale du banc. Cela suggère que, bien que les flux ultérieurs ont été en mesure de remobiliser une partie du dépôt, ils n'ont pas été capables de détruire le noyau de la barre formé lors de la crue. Les bancs $C$ et D ont été rapidement ré-incisé et subdivisés. Le banc C a été profondément remanié par la plus grande crue post-jökulhlaup de 1996. Une partie relativement importante du banc C est néanmoins restée intacte jusqu'en 2003. Le banc D a été remanié par le chenal actif de la Skeiðará et sa superficie était déjà fortement réduite en 2003. En 2003, la Skeiðará commençait à se déplacer vers l'ouest, et la Skeiðará ouest a drainé une partie accrue du débit proglaciaire. De 2003 à 2009, la Skeiðará orientale a été abandonnée, la Skeiðará ouest drainant ainsi temporairement la totalité des flux. Puis la Skeiðará a été totalement abandonnée, capturée par la rivière Gígjukvísl en 2009. La conséquence immédiate de cette capture fut l'arrêt brutal du remaniement du secteur oriental de la Skeiðará et du banc B ainsi que l'accélération de la remobilisation de la Skeiðará occidentale et des bancs $C$ et $D$. Seuls de minuscules fragments du banc C et quasiment aucun du banc D ont survécu à cette phase.

Bridge et Lunt (2006) ainsi que Rubin et al. (2006) distinguent les bancs unitaires des bancs composites selon leur rapport longueur/largeur. Les bancs unitaires ont des rapports longueur/largeur de 5 à 5,5, tandis que les bancs composites ont des rapports longueur/largeur de 3 à 3,5 (Lunt et al., 2004 ; Rubin et al, 2006). A partir de l'analyse de données de terrain et photo-interprétées, Sambrook Smith et al. (2005), ainsi que Kelly (2006), ont obtenu des mesures moyennes réalistes du rapport longueur/largeur de 2,97 et 3,76 respectivement. Ce résultat suggère que les bancs de tressage observés dans la réalité sont principalement des bancs composites. La longueur d'onde des bancs unitaires (l'espacement entre les bancs) varient généralement de 3 à 12 largeurs de chenal (Lunt et al., 2004). Lunt et 
al. (2004) et Rubin et al. (2006) ont constaté (en utilisant les mêmes données) que la longueur des bancs unitaires équivalait le plus souvent à 2,5 à 4 fois la largeur de chenal, ce qui équivaut en moyenne à 3,5 fois la largeur (les mesures variant entre 2 et 7 fois la largeur).

Les dimensions des trois bancs et de leurs chenaux sont fournies dans le tableau 1. Les données indiquent que les trois bancs sont relativement similaires dans leur rapport longueur/largeur avec une valeur moyenne de 2,3, ce qui correspond à l'extrémité inférieure de la gamme de valeurs rapportée pour d'autres cours d'eau. La longueur des bancs semble être équivalente à la largeur du chenal au point d'affouillement amont. Les bancs ont un rapport longueur/largeur de chenal moyen de 3,77. Globalement, la morphologie des principales unités de dépôts dans la Skeiðará semble être contrôlée par la géométrie du chenal de crue. Leurs dimensions sont en accord avec la "bar scaling theory ". Parce que les dépôts de jökulhlaup sont souvent composés de matériaux plus grossiers et sont topographiquement (et stratigraphiquement) plus élevés que les flux qui se produisent entre les jökulhlaups, leur remaniement partiel est surtout assuré par la mobilité latérale des cours d'eau tressés plutôt que par la submersion et un remaniement de l'ensemble de la surface des bancs. Par conséquent, les fragments de banc qui ont survécu aux processus de remaniement deviennent étroits plus rapidement qu'ils ne se raccourcissent en longueur. Le rapport longueur/largeur des bancs restants augmentent donc au fil du temps.

Cette observation a été testée en mesurant et en suivant l'évolution de tous les fragments des bancs $A, B$ et $C$ depuis leur création jusqu'en 2012. La fragmentation a été très irrégulière entre 1997 et 2012. Toutefois, les résultats indiquent que pour les trois bancs, chaque nouveau fragment de banc créé a un rapport longueur/largeur plus élevé que le banc d'origine. Le ratio longueur/largeur moyen des fragments du banc A est de 4,59, contre 1,81 pour le banc d'origine. Concernant le banc B, le ratio est de 2,8 pour la barre d'origine et de 6,87 en moyenne pour les fragments. Le ratio longueur/largeur moyen des fragments du banc $C$ est de 3,6, contre 2,52 pour le banc d'origine. Ce résultat donne un rapport longueur/largeur moyen des fragments des bancs de 5,02 contre 2,3 en moyenne pour les bancs originaux. Les fragments de bancs remaniés sont donc en moyenne plus de deux fois plus longs que les banc d'origine, et se situent à la limite supérieure de la fourchette de valeur des ratios longueur/largeur des bancs de tressage (Sambrook Smith et al., 2005 ; Kelly, 2006).

En soi, le fait que les bancs de jökulhlaup remobilisés aient un rapport longueur/largeur plus élevé que les bancs de jökulhlaup primaires et les bancs associés aux débits inférieurs n'est pas un critère suffisant pour caractériser un dépôts de jökulhlaup (Marren, 2002b, 2005). Néanmoins, couplé au fait que les fragments de banc de jökulhlaup conservent généralement en surface la topographie imprimée par la crue la plus morphogène, souvent dotée de marques de blocs de glace, ils peuvent renforcer la liste des critères habituellement utilisés pour identifier les dépôts de crues BFHM. En outre, les observations faites ici peuvent aider à la reconstruction paléohydraulique des crues, car ils peuvent être utilisés pour aider à déduire les dimensions des bancs originaux à partir des fragments préservés. De même, étant donné que la longueur, l'espacement et l'épaisseur du banc sont liés, ces observations peuvent aider à la reconstruction de la géométrie à la fois préservé et originale des dépôts de crue dans l'enregistrement sédimentaire.

\section{Introduction}

The aim of this paper is to investigate the long-term evolution and modification of glacial outburst flood (jökulhlaup) deposits, using the 1996 jökulhlaup on Skeiðarársandur, southeast Iceland as a case study. The study focuses on the way in which flood bars in the Skeiðará channel main are reworked, removed and change shape during the period following the flood.

The geomorphological and sedimentary record of flood deposits is a product of the processes that operated during the flood, including the flood peak and waning stage, coupled with the processes that occur after the flood modifying the deposit and overprinting the landscape with a record of 'normal' processes. This interaction between 'extreme' and 'normal' events was first explored in terms of landscape response by Wolman and Gerson (1978) who suggested that the scale of event dominating a particular landscape depends partly on the environmental setting, with humid temperate environments tending to be dominated by smaller, more regular flood events and arid environments tending to be dominated by larger, rarer events due to both the absence of both low-magnitude flows and stabilising vegetation. The relative role of large floods in forming proglacial landscape and sedimentary records has been discussed by Marren et al. (2002) and Marren (2005). An example of flood and non-flood deposits reworking and overprinting each other to produce a final sedimentary record is provided by Marren (2002a), which describes the deposits exposed where the Gígjukvísl river cuts through the moraine belt encircling Skeiðarárjökull. Advance and retreat of Skeiðarárjökull has resulted in lacustrine deposits being overridden and removed by flood deposits, then overridden and removed by a 'normal' braided river, before incision by a second flood cutting through the moraine belt.

Although there have been many case studies of the impacts of individual floods, there have been fewer studies that have considered the long-term fate of flood deposits, and their final appearance in the geomorphological or sedimentary 
record following a period of reworking, over-printing and burial. Warburton (1994) has shown that for a relatively small rainstorm flood the braided channel produced during the flood was re-converted to a single channel in one melt season. A long-term analysis of landscape recovery following the very large 1918 Katla outburst flood (Duller et al., 2014) shows that in terms of net change in volume of sediment added or subtracted to the outwash plain the landscape recovered in approximately 120 years. Despite this, the landscape is still recognisably impacted by the 1918 jökulhlaup (Russell et al., 2010) and sedimentary deposits of the flood are still preserved (Duller et al., 2008). This outcome may be because a large portion of the sediment removal was due to removal by groundwater exfiltration rather than erosion of surface deposits (Duller et al., 2014).

Of the recent jökulhlaups to have occurred in Iceland, the largest and most spectacular was the November 1996 jökulhlaup on Skeiðarársandur (Russell and Knudsen, 1999; Russell et al., 2006). It is too soon to assess the full postflood recovery of the 1996 Skeiðarársandur jökulhlaup and determine what the final geomorphological and sedimentary record of this event will comprise. However, the long-term analysis of the 1918 Katla jökulhlaup indicates that the pattern of landscape recovery from large jökulhlaups is broadly negative exponential, with the most rapid changes occurring in the first few decades (Duller et al., 2014). The study by Smith et al. (2006) of elevation changes in the flood channels for the first five years following the 1996 jökulhlaup is therefore useful in describing the initial recovery and indicating the likely trajectory of future changes.

Large scale variations in the impact of the 1996 jökulhlaup on Skeiðarársandur were largely driven by variation in the proximal sandur topography, mostly due to the presence of the Gígjukvísl ice-marginal depression running parallel to the central part of the glacier which had formed because of retreat of the glacier away from its Little Ice Age maximum in the years prior to the jökulhlaup (Russell and Knudsen, 1999; Magilligan et al., 2002). The greatest volume of deposition occurred in the Gígjukvísl ice-marginal depression, which had never previously been impacted by a major jökulhlaup (Russell and Knudsen, 1999, 2002a; Smith et al., 2006). Significant deposition also occurred in the Skeiðará channel, which had been the major floodway for most previous large floods, although there were no major morphological changes (Marren and Schuh, 2009). Consequently, most post-flood reworking occurred in the Gígjukvísl depression (Smith et al., 2006). Little surface lowering occurred in the Skeiðará channel between 1996 and 2001 (Smith et al., 2006) although lateral reworking of jökulhaup deposits was ongoing throughout this period (Marren et al., 2002; Marren and Schuh, 2009).

This paper revisits the Skeiðará jökulhlaup channel described by Marren et al. (2002) and Marren and Schuh (2009). Ongoing retreat of the Skeiðarárjökull glacier has diverted all flow from the Skeiðará river into the Gígjukvísl, meaning that apart from a small amount of water entering from Morsájökull, the Skeiðará river system has been abandoned since 2009. Barring a major readvance of Skeiðarárjökull, the Skeiðará channel is now effectively a terrace, and the morphology and sedimentology of this river have reached their 'final' form. Aerial photography from 1991/1992, 1996 (during the jökulhlaup), 1997, 2003 and 2012 has been georeferenced in ArcGIS and is used to describe the formation and modification of flood bars in the Skeiðará channel. The paper then uses the Skeiðará jökulhlaup bars as a basis to consider the morphology of reworked flood bars more broadly, and thus derive new conclusions on (1) criteria for identifying jökulhlaups in the geomorphological record, and (2) the relationship between flood and non-flood deposits in proglacial landscapes.

\section{The Skeiðará jökulhlaup bars}

\subsection{Formation, geomorphology and sedimentology}

Throughout the Twentieth Century, the Skeiðará was the largest of the three rivers draining Skeiðarájökull (Boothroyd and Nummedal, 1978; fig. 1). The overall morphology of the proximal Skeiðará is controlled by a combination of fixed topographic features (the high ground and flood defences of Skaftafell to the east, and Little Ice Age moraines in the north and west), repeated large floods and entrenchment of the channel associated with ongoing glacier retreat (Boothroyd and Nummedal, 1978; Marren et al., 2002; Marren, 2004). Jökulhlaups sourced from the subglacial Grímsvötn occurred throughout the Twentieth Century at intervals of 1 to 10 years with discharges ranging from 600 to 45,000 $\mathrm{m}^{3} \mathrm{~s}^{-1}$ (Björnsson, 2002, 2009). The largest jökulhlaups occurred in 1934, 1938 and 1996 in conjunction with subglacial volcanic eruptions. During the 1996 jökulhlaup approximately $40 \%$ of the total volume of floodwaters drained via the Skeiðará channel, giving a peak discharge in the river of 15,000 to $20,000 \mathrm{~m}^{3} \mathrm{~s}^{-1}$.

Close to the glacier outlet, the 1996 jökulhlaup floodwaters divided around a moraine fragment into two branches that are usually referred to as the western and eastern Skeiðará (Russell and Knudsen, 1999). The eastern and western branches are separate channels approximately $3 \mathrm{~km}$ and $5 \mathrm{~km}$ long respectively, which re-join $3 \mathrm{~km}$ upstream of the Skeiðará road bridge (fig. 2). Flood extents during the 1996 jökulhlaup were constrained by the high ground of the Skaftafellsheiði ridge and the flood defence protecting the Skaftafell National Park campground in the east, and by the 
gradually sloping palaeo-outwash surface on the western side of the channel (Snorrason et al., 2002). Flow in the eastern Skeiðará expanded into the valley of Morsájökull, inundating a large area close to the confluence of the Morsá valley, but producing relatively little geomorphological change. Shallow inundation with minimal geomorphological change also occurred across a large area of channel on the true right of the eastern Skeiðara and on the true right of the main Skeiðará channel, between the confluence of the west and east branches and the Route 1 road bridge.

The pattern of deposition was similar in both the eastern and western Skeiðará, with bank-attached alternate bars occurring on the western flank of both channels (fig. 3). A large bar formed at the confluence of the two branches of the Skeiðará (marked as ' $A$ ' in fig. 3) and in the eastern Skeiðará deposition occurred where the flows expanded and turned due south downstream of the Morsá confluence. In the main Skeiðará channel sediment was transported through the active channel in diamond shaped unit bars with lobate fronts, each approximately 1000 to $1500 \mathrm{~m}$ long. Larger compound bars formed where these unit bars became exposed and began to amalgamate (partly exposed unit bars are mapped in the centre of the main Skeiðara channel in fig. 3). The most upstream compound bar formed where the eastern Skeiðará expanded downstream of the Skaftafell construction, forming a streamlined bar that grew into a more complex compound bar over the course of the flood (fig. 3; marked as 'B').

A second major depositional area formed on the western side of the channel. In the 1996 flood aerial photography this bar was mostly submerged but with numerous grounded ice-blocks exposed on the crests of unit bars. This bar occupied approximately one-third of the channel width, with deeper, faster water occupying the rest of the channel (fig. 3; marked as ' $C$ '). The distal end of this bar was influenced by the flood defence barriers on the western side of the Skeiðará road bridge. The bar almost reached the Skeiðará bridge but downstream of this point the flood flows quickly became unconfined and a series of smaller bars developed. The 1997 post-flood photography shows the depositional area extending across two thirds of the channel, with the section in the centre of the channel presumably formed later in the flood and more heavily dissected by waning stage flows (fig. 3; marked as 'D'). The flood barrier along the eastern flank of the Skeiðará channel acted as the focus for deposition on the eastern flank of the main Skeiðará channel, trapping sediment along its full length.

Marren et al. (2002) and Marren and Schuh (2009) described the geomorphology and sedimentology of the bars identified here as bars $\mathrm{C}$ and $\mathrm{D}$. The jökulhlaup bar surface can be clearly identified by the presence of numerous iceblock obstacle marks. Waning stage dissection and reworking split the bar into sub-bars which formed the starting point for subsequent reworking. By 2001, the 1996 jökulhlaup deposits in the Skeiðará channel were 2.5 to $3 \mathrm{~m}$ higher than adjacent reworked bar surfaces and the peak summer ablation controlled flow depths (Marren et al., 2002). Marren et al. (2002) suggested that the dimensions of this bar scaled to flood channel dimensions, using theory described by Thorne et al. (1993). This point is discussed further below.

The sedimentology of the bar was examined using ground-penetrating radar by Marren and Schuh (2009). The sedimentary record reflects the depositional history, with initial scour, followed by aggradation, and late-stage reworking. A dune train (wavelength $10 \mathrm{~m}$, amplitude $1 \mathrm{~m}$ ) is interpreted as representing the first deposits of the 1996 flood following initial scour. Overlying the dunes are up to $10 \mathrm{~m}$ of sheet-like deposits with boulder clusters, interpreted as the product of the main depositional phase of the flood. The sheet deposits are overlain in some locations by crosscutting scour and fill structures interpreted as late-stage reworking. This flow-stage dependent aggradation and variability has been described from 1996 flood deposits viewed in sedimentary sections elsewhere on Skeiðarársandur (Russell and Knudsen, 2002b).

\subsection{Post-1996 modification}

Reworking of the 1996 jökulhlaup deposits began during the 1997 ablation season. Since then peak summer discharges, rainstorm events and a number of minor outburst floods in the mid-2000s continued to modify the Skeiðará channel up to 2009 when the channel was abandoned. As mentioned above, retreat of Skeiðarárjökull has reorganised the proglacial drainage network so that meltwaters now flow into the Gígjukvísl ice-marginal depression and into the Gígjukvísl river system draining the central part of the outwash plain. The Skeiðará channel is now essentially a terrace, receiving water only from the tributary valley fed by Morsájökull. This drainage reorganisation is due to the high rates of glacier retreat that have occurred on all glaciers in this region since 2000, and is a similar albeit larger scale process to that which has been described in detail on the adjacent Skaftafellsjökull (Marren and Toomath, 2013, 2014). As with Skaftafellsjökull, topographic forcing means that most proximal rivers on Skeiðarársandur are now single channel rivers for considerable distances downstream.

Aerial photography from 1997, 2003 and 2012 indicates the extent of channel change over the period of post-flood recovery (fig. 4). All traces of the 1996 flood were quickly removed from the main Skeiðará channel. Field observations in 2001 indicate that lateral reworking of the bar margins occurred, which bisected and gradually reduced the area of the bars, although no flows occurred that were able to completely inundate and thus destroy all surface traces of the 1996 flood (fig. 4). In the eastern Skeiðará proximal bar areas were reworked relatively quickly, mostly before 2003. 
The deposits at the distal end of bar B were partly removed, restoring the outline of the bar to a lozenge shape. The fragments of this bar tail that survived were reworked into mid-channel islands in the 1997 channel. The area of bar B with traces of the 1996 jökulhlaup was reduced, although the reworked fragments maintained the overall shape of the bar, suggesting that although the later flows were reworking the surface, they were not capable of destroying the bar core formed during the flood. Bars $\mathrm{C}$ and $\mathrm{D}$ were quickly dissected. Bar $\mathrm{C}$ was mostly dissected by the larger post 1996 events flow events, and a relatively large portion of it remained in 2003. Bar D was reworked by the active Skeiðará, and was already greatly reduced in size by 2003. Bar A at the confluence of the western and eastern Skeiðará was still largely intact in 2003.

By 2003 the outlet of the Skeiðará was beginning to shift westwards, and the western Skeiðará took an increased portion of the flow. From 2003 to 2009, the eastern Skeiðará was abandoned; shifting all flow in the western Skeiðará, then the Skeiðará system was abandoned completely, with all meltwater leaving the glacier via the Gígjukvísl channel by 2009. The consequence of this was that reworking of the eastern Skeiðará and bar B ceased, and the reworking of the western Skeiðará and bars C and D accelerated. The bar at the confluence of the western and eastern Skeiðará was heavily reworked in the post 2003 period, and most of the surface close to the western Skeiðará was reworked. Only the cores of the alternate bars in the western Skeiðará remained by 2009, and only tiny fragments of bar C and almost none of bar D survived this phase of reworking.

Overall, the trend from 1996 to 2009 was for relatively rapid lateral and surface reworking of bar surfaces from 1997 to 2003 in the eastern and main Skeiðará channels, followed by abandonment of the eastern Skeiðará, preserving the remaining bar surfaces, but accelerating erosion in the western Skeiðará and enabling the bar depositing in the main Skeiðará to be almost completely reworked to an extent that would not have happened without the drainage reorganisation. However, despite the extensive surface reworking, bar B preserved its overall shape throughout the study period and bar $\mathrm{C}$ preserved its overall form until the drainage reorganisation. These observations, combined with those made earlier in Marren et al. (2002) lead to a series of observations. Firstly, the large-scale depositional morphology of the Skeiðará floods was controlled by the overall morphology of the flood channel, with a number of fixed features such as the Skaftafell heiði high ground and flood defences, and the Little Ice Age moraines determining the broad-scale deposition patterns. Secondly, within the broad-scale framework, deposition was scaled to the channel dimensions (width and depth) in a pattern consistent with the scaling of 'regular' braided rivers. Thirdly, the reworking of the flood bars was systematically changing the length to width ratio of deposits such that reworked flood deposits can be distinguished from primary depositional features based on their morphology. These observations on scaling and reworking are tested in the following sections.

\section{The scaling of braid bars}

It is thought that many aspects of braided rivers are scale invariant (Bristow and Best, 1993). This supposition is readily apparent when examining braided rivers of different scales, as they generally display a gross similarity of bar form across a wide range of scales (Sapozhinikov and Foufoula-Georgiou, 1996). The easiest parameter to measure is bar shape, usually expressed as length to width ratio. A long history of modification by variable flows can result in complex bar shapes (Bridge, 1993), but observations of braid bar formation indicate that a simple, unmodified bar will have a regular shape (Ashmore, 1982; Ferguson, 1993; Ashworth, 1996). Bridge (1985) suggests that bars are related to the streamlined landforms described by Komar (1983, 1984), which closely correspond to the half-lemniscate loop shape which usually has a length to width ratio of 3-4:1 (Komar, 1983). River islands may be longer than other streamlined landforms due to deposition on the 'tail': the data of Komar $(1983,1984)$ had a mean length-width ratio for river islands (not necessarily braid bars) of 4.3:1. More recently, Meshkova and Carling (2013) found that streamlined islands in a large dataset of rivers had a length to width ratio of 3:1 across a large range of scales.

Bridge and Lunt (2006) and Rubin et al. (2006) distinguish between the scaling of unit bars and of compound bars, which are formed from the amalgamation and modification of several unit bars. Unit bars form downstream of erosional pools, and are elongated, with a lobate front (Lunt et al., 2004). The half-lemnsicate loop shape is more usually associated with compound bars, where flow divides and re-joins around a bar, with the flow in each anabranch consisting of a single curved segment. Unit bars have length to width ratios of 5-5.5:1, whilst compound bars have length to width ratios of three to 3-3.5:1 (Lunt et al., 2004; Rubin et al., 2006). Using large datasets obtained from aerial photographs and field data, Sambrook Smith et al. (2005) and Kelly (2006) obtain real-world average length to width ratios of 2.97 and 3.76 respectively, suggesting that real world 'braid bars' are mostly compound bars.

The theory underlying the scaling of barforms in rivers is derived from work on pool-riffles and meandering rivers (Carling and Orr, 2000). Thorne et al. (1993) suggest that $L=\pi w$ where $L$ is bar length and $w$ is channel width, based on work by Yalin (1977), which was concerned with meander wavelength $\left(L_{m}=2 \pi w\right)$. The bar scaling parameter is derived from the fact that two point bars occur in one meander wavelength. This equation is therefore for the spacing 
rather than the length of bars as it is a measure of bar crest-to-crest (or pool-to-pool) spacing. Hey (1976) undertook a similar analysis but made different initial assumptions. Yalin (1977) assumed that the macroturbulent length scale for eddies and associated helicoidal flow cells responsible for repeating channel features was the width of the channel. Based on observations by Hey and Thorne (1975), Hey (1976) suggests that macroturbulent eddies are probably associated with two flow cells in a channel width. Consequently meander spacing is scaled to $L=4 \pi w$. Applying Hey's (1976) equation to bar spacing yields $L=2 \pi w$. Support for this is provided by Hey and Thorne (1986) from their measurements of 62 gravel bed rivers in the United Kingdom which yielded an average meander arc length or riffle spacing of $L=6.31 \mathrm{w}$, which is almost directly equivalent to $2 \pi w$, although this finding is not universal (Carling and Orr, 2000).

These two equations ( $L=\pi w$ and $L=2 \pi w$ ) can be reconciled by observing that Thorne et al. (1993) used an equation based on bar spacing theory to estimate bar length and that the length of exposed bar surface must typically cover approximately half the distance between the upstream and downstream pools at either end of the bar. This deduction is supported by the fact that unit bar wavelengths (bar spacing) typically range from three to 12 channel widths (Lunt et al., 2004); whilst Lunt et al. (2004) and Rubin et al. (2006) found (using the same data) that unit bar length was most commonly two and one half to four channel widths, averaging three and one half widths (but ranging from two to seven widths).

The channel-forming or dominant, discharge in braided rivers is usually thought to be somewhat below bankfull (Bridge, 1985, 1993; Thorne et al., 1993). Most braided proglacial rivers are dominated by the annual ablation peak discharge (Fenn and Gurnell, 1987), and proglacial channels are likely to scale to this discharge. An exception is in those locations where proglacial fluvial systems are affected by repeated high magnitude floods that are very much larger than 'normal' ablation controlled discharges. In these situations, stable barforms may be much larger and related to flood flow discharges and channel widths (Fahnestock and Bradley, 1973; Marren et al., 2002; Marren, 2005).

Bar reworking by discharges of varying magnitudes, and migration and growth mean that few large-flood bars retain the idealised form. If dissected fragments are low enough that they can interact with the flow, they become bars in their own right, scaling to the dimension of the divided channel. If the dissected fragments are stable because they are too high to be inundated, or too coarse-grained to be mobile, they become islands, and the channels flowing between the islands may develop braid bars of their own. It is these stable bar fragments which are hypothesised to increase their length-width ratio during post-flood reworking.

\section{The form of Skeiðará jökulhlaup bars}

\subsection{Scaling}

As described above, there were three major mid-channel compound bars present in the Skeiðará channel associated with the 1996 jökulhlaup. Bar B formed downstream of the scour constriction just before the eastern Skeiðará joins the main Skeiðará. Bar C formed where the western Skeiðará expanded downstream of the confluence of the two branches, and bar D formed as a sub-bar of bar C, in the main Skeiðará. The dimensions of the three bars and their associated channels are given in table 1 . Given that the bars evolved rapidly during the jökulhlaup, and their post-flood form was modified by waning stage reworking, these dimensions are approximate.

The data indicates that the original morphology of the three bars is relatively consistent in their scaling. Their location and the channel widths that controlled their scales were largely controlled by the fixed points at the boundaries of the channel: the high ground of Skaftafell and the flood barrier to the east, the confluence of the two branches of the Skeiðará in the centre of the channel, and to a lesser extent the higher outwash surfaces on the west of the flood channel that were inundated but not eroded during the jökulhlaup. Bar $\mathrm{C}$ was the only bar for which the position was controlled by mid-channel flow convergence (with 'channel width' defined by the extent of deeper flow between submerged unit bars), and even so, the extent of bar $\mathrm{C}$ was strongly controlled by the location of the adjacent bar $\mathrm{B}$.

The three bars have an average length-width ratio of 2.3, which is at the lower end of the range of dimensions reported for other rivers (Sambrook Smith et al., 2005; Kelly, 2006). This relatively short length may reflect the formation of the bars in only one flood. Compound bars are usually become elongated as they are created and modified through the amalgamation of unit bars over multiple events (e.g. Sambrook Smith et al., 2006; Nicholas et al., 2013). The bar length appears to be scaled to the width of the channel at the point of upstream scour. When this dimension is used, the bars are an average of 3.77 channel widths long, which is in accord with the bar scaling theory described above. Overall then, the gross morphology of the major depositional units in the Skeiðará appear to be controlled by flood channel geometry, and their dimensions are in accord with bar scaling theory.

\subsection{Pattern of jökulhlaup bar reworking}


As described above, reworking of the major within-channel braid bars formed during the 1996 jökulhlaup began during the flood. The depressions created by waning stage reworking became the focal points for post-flood reworking, with channels around the flood bars becoming major braided channels in their own right, and cross-flood bar channels becoming pathways for the small to medium sized floods that have occurred since the 1996 jökulhlaup. Because the jökulhlaup deposits are topographically (and stratigraphically) higher than the flows that occur between jökulhlaups and are frequently coarser grained, most bar reworking is by lateral migration of the braided channels rather than by overtopping and surface reworking. The implication of this is that bar fragmentation occurs due to removal of material from the sides of the bars. The bar and fragments of the bar therefore become narrower over time. Shortening of bars and bar fragments occurs when the path of the laterally migrating channel intercepts the bar head or tail. The consequence of this is that bar fragments that have survived the reworking processes become narrower more quickly than they become shorter, and the length-width ratio of the remaining flood deposits becomes longer over time.

This observation was tested by measuring all of the fragments of bars A, B and C as they were created and modified from 1997 to 2012. The results (fig. 5) indicate that for all three bars, every bar fragment created has a longer lengthwidth ratio than the original bar. For bar A the average length-width ratio of bar fragments is 4.59 , compared to 1.81 for the original bar. For bar B the values are 2.8 for the original bar and an average of 6.87 for the bar fragments, and for bar $\mathrm{C}$ the fragments had an average length-width ratio of 3.6, in contrast to the original 2.52. This gives an average bar fragment length width ratio of 5.02, compared with the primary bar average of 2.3. Reworked bar fragments are therefore more than twice as long as the original bar on average, and at the upper limit of the range for length-width ratios of braid bars (Sambrook Smith et al., 2005; Kelly, 2006). No bar fragment was observed with a shorter lengthwidth ratio than the original bar. Some bar fragments retain their overall streamlined bar morphology, but in other cases the development of nascent meandering in the adjacent channels results in irregular bar morphologies. There was no evidence of bars changing shape in a progressive manner (increasing the length-width ratio over time), due to the magnitude of changes which occurred between the successive aerial photographs.

When the lengths and widths of the original and modified bars are compared to the datasets produced by Sambrook Smith et al. (2005) and Kelly (2006) an interesting pattern emerges (fig. 6). A trendline fitted through the three original bars matches the slope of the Sambrook Smith and Kelly dataset, albeit offset from the trendline in a way which indicates the Skeiðará jökulhlaup bars are slightly wider for a given length than the bars in the global dataset. When the mean lengths and widths for each bar fragment are plotted on the same graph, their general position is still close to the global trend, indicating that the overall range of possible bar shapes is relatively small. However, a trendline through the modified bar data points has a much lower slope than either the global dataset, or the unmodified bar data, indicating that the bar fragments are very narrow across a wide range of lengths (fig. 6).

Reworking and elongation of bars occurs across all scales of braided and anabranching river (Nicholas et al., 2013). In particular, islands stabilised by vegetation in anabranching rivers tend to become longer than unstable vegetationfree bars. Thus, by itself, the observation that reworked flood deposits have longer length-width ratios than primary flood deposits and bars associated with lower discharge is not a unique criteria for identifying jökulhlaup deposits (Marren, 2002b, 2005). Nonetheless, coupled with the fact that the bar fragments generally preserve the original flood surface associated with the main stage of the flood the longest, and frequently feature ice-block obstacle marks, they may form a useful part of the suite of criteria typically used to identify high magnitude flood deposits.

Additionally the observations made here may assist in palaeohydraulic reconstruction of floods, as they may be used to help infer original bar dimensions from preserved fragments. Similarly, given that bar length, spacing and thickness are related (Sambrook Smith et al., 2005; Kelly, 2006; Rubin et al., 2006), these observations may help in reconstructing both the preserved and original geometry of flood deposits in the sedimentary record. Unlike the situation in sandy braided rivers (Sambrook Smith et al., 2010), there is a clear difference in the depth of scour, grainsize of deposited material and internal structure of the Skeiðará jökulhlaup bars compared to between-flood braided river deposits. Given the thickness and height of the 1996 jökulhlaup deposit (Marren and Schuh, 2009), it is likely that the reworking has not removed the full thickness of the flood deposits, but it is equally likely that the original dimensions of jökulhlaup bars will not be preserved. The observations here indicate that original bar thickness is may be preserved near the bar core, but bar length and width will be significantly modified, with width more likely to be modified than length. Further investigation is needed, using ground-penetrating radar, to gain further insights into the geometry of partially reworked flood deposits at depth.

\section{Conclusions}


The overall form of a flood deposit is as much a product of post-flood reworking as it is of the flood itself. Despite this, there have been relatively few studies of the long-term evolution of jökulhlaup deposits. This study has described the changes in the proximal Skeiðará channel since the 1996 jökulhlaup, up to 2009.

The development of the Skeiðará since 1996 indicates that lateral and, to a lesser extent, surface reworking by migrating braided rivers is the dominant process in landscape recovery. Lateral reworking lowers the surface elevation of the flood deposit, but allows central bar fragments at higher elevations to be preserved. Given that migrating nonflood channels will not reach the same depths as the flood channel, it is likely that flood deposits are preserved underneath the reworked surface. This has been observed in outcrop in other parts of Skeiðarársandur, but the opportunity now exists for this to be tested using ground-penetrating radar in the abandoned Skeiðará channel.

Large jökulhlaup bars are formed from the amalgamation of smaller unit bars, as happens in other braided rivers, but at a larger scale, indicating that jökulhlaup deposits are largely scale-invariant. However, the scale of the flood bar geometry relative to the topographic setting, the interaction with smaller-scale braided river deposits formed by reworking, and the presence of features such as ice-block obstacle marks and gravel dunes make jökulhlaup bars a distinctive depositional environment, recognisable in the sedimentary record.

\section{Acknowledgements}

The field observations in this paper were made whilst undertaking fieldwork supported by grants from the Earthwatch Institute awarded to Andrew J. Russell. Emma Naden and Erwan Roussel are thanked for providing the French translation.

\section{References}

Ashmore P.E. (1982) - Laboratory modelling of gravel braided stream morphology. Earth Surface Processes 7, $201-225$.

Ashworth P.J. (1996) - Mid-channel bar growth and its relationship to local flow strength and direction. Earth Surface Processes and Landforms 21, 103-123.

Björnsson H. (2002) - Subglacial lakes and jökulhlaups in Iceland. Global and Planetary Change 35, $255-271$.

Björnsson H. (2009) - Jökulhlaups in Iceland: sources, release and drainage. In Burr D.M., Carling P.A., Baker V.R. (Eds.): Megaflooding on Earth and Mars. Cambridge University Press, 51-64.

Boothroyd J.C., Nummedal D. (1978) - Proglacial braided outwash: a model for humid alluvial fan deposits. In Miall A.D. (Ed.): Fluvial Sedimentology. Canadian Society of Petroleum Geologists Memoir 5, 641-668.

Bridge J.S. (1985) - Paleochannel patterns inferred from alluvial deposits: a critical evaluation. Journal of Sedimentary Petrology $55,579-589$.

Bridge J.S. (1993) - The interaction between channel geometry, water flow, sediment transport and deposition in braided rivers. In Best J. L., Bristow C. S. (Eds.): Braided Rivers. Geological Society Special Publication 75, 13-72.

Bridge J.S., Lunt I.A. (2006) - Depositional models of braided rivers. In Sambrook Smith G.H, Best J.L., Bristow C.S., and Petts G.E. (Eds.): Braided Rivers: Process, Deposits, Ecology and Management. International Association of Sedimentologists Special Publication 36, 11-50.

Bristow C.S., Best J.L. (1993) - Braided rivers: perspectives and problems. In Best J.L., Bristow C.S. (Eds.): Braided Rivers. Geological Society Special Publication. 75, 1-11.

Carling P.A., Orr H.G. (2000) - Morphology of riffle-pool sequences in the River Severn, England. Earth Surface Processes and Landforms 25, 369-384.

Duller R.A., Mountney N.P., Russell A.J., Cassidy N.J. (2008) - Architectural analysis of a volcaniclastic jökulhlaup deposit, southern Iceland: sedimentary evidence for supercritical flow. Sedimentology 55, 939-964.

Duller R.A., Warner N.H., McGonigle C., De Angelis S., Russell A.J., Mountney N.P. (2014) - Landscape reaction, response, and recovery following the catastrophic 1918 Katla jökulhlaup, southern Iceland, Geophysical Research Letters 41, 4214-4221.

Fahnestock R.K., Bradley W.C. (1973) - Knik and Matanuska Rivers, Alaska: a contrast in braiding. In Morisawa M. (Ed.): Fluvial Geomorphology. Binghampton Symposia in Geomorphology 4, 220-250.

Fenn C.R., Gurnell A.M. (1987) - Proglacial channel processes. In Gurnell A.M., Clarke M.J. (Eds.): Glacio-fluvial Sediment Transfer. John Wiley \& Sons, London, 423-472,

Ferguson R.I. (1993) - Understanding braiding processes in gravel-bed rivers: progress and unsolved problems. In Best J.L., Bristow C.S. (Eds.): Braided Rivers. Geological Society Special Publication 75, 73-87.

Hey R.D. (1976) - Geometry of river meanders. Nature 262, 482-484.

Hey R.D., Thorne C.R. (1975) - Secondary flows in river channels. Area 7, 191-195.

Hey R.D., Thorne C.R. (1986) - Stable channels with mobile gravel beds. Journal of Hydraulic Engineering 112, 671-689.

Kelly S. (2006) - Scaling and hierarchy in braided rivers and their deposits: examples and implications for reservoir modelling. In Sambrook Smith G.H. Best J.L., Bristow C.S., Petts G.E. (Eds.): Braided Rivers: Process, Deposits, Ecology and Management. International Association of Sedimentologists Special Publication 36, 75-106.

Komar P.D. (1983) - The shapes of streamlined islands on earth and Mars: experiments and analysis of the least-drag form. Geology $11,651-654$. 
Komar P.D. (1984) - The lemniscate loop - comparisons with the shapes of streamlined landforms. Journal of Geology 92, 133145 .

Lunt I.A., Bridge J.S., Tye R.S. (2004) - A quantitative, three-dimensional depositional model of gravelly braided rivers. Sedimentology 51, 377-414.

Magilligan F.J., Gomez B., Mertes L.A.K., Smith L.C., Smith N.D., Finnegan D., Garvin J.B. (2002) - Geomorphic effectiveness, sandur development, and the pattern of landscape response during jökulhlaups: Skeiðarársandur, southeastern Iceland. Geomorphology 44, 95-113.

Marren P.M. (2002a) - Fluvial-lacustrine interaction on Skeiðarársandur, Iceland: implications for sandur evolution. Sedimentary Geology 149, 43-58.

Marren P.M. (2002b) - Criteria for distinguishing high magnitude flood events in the proglacial fluvial sedimentary record. In Snorasson A., Finnsdóttir H.P., Moss M. (Eds.): The Extremes of the Extremes: Extraordinary Floods. IAHS Publication 271, 237241.

Marren P.M. (2004) - Present-day sandurs are not representative of the geological record: Sedimentary Geology 152, 1-5 (2002). Sedimentary Geology 164, 335-340.

Marren P.M. (2005) - Magnitude and frequency in proglacial rivers: a geomorphological and sedimentological perspective. EarthScience Reviews 70, 203-251.

Marren P.M., Schuh M. (2009) - Criteria for identifying jökulhlaup deposits in the sedimentary record. In Burr D.M., Carling P.A., Baker V.R. (Eds.): Megaflooding on Earth and Mars. Cambridge University Press, 225-242.

Marren P.M., Toomath S.C. (2013) - Fluvial adjustments in response to glacier retreat: Skaftafellsjökull, Iceland. Boreas 42, 5770.

Marren P.M., Toomath S.C. (2014) - Channel pattern of proglacial rivers: topographic forcing due to glacier retreat. Earth Surface Processes and Landforms 39, 943-951.

Marren P.M., Russell A.J., Knudsen Ó. (2002) - Discharge magnitude and frequency as a control on proglacial fluvial sedimentary systems. In Dyer F., Thoms M.C., Olley J.M. (Eds.): The Structure, Function and Management Implications of Fluvial Sedimentary Systems. IAHS Publication 276, 297-303.

Meshkova L.V., Carling P.A. (2013) - Discrimination of alluvial and mixed bedrock-alluvial multichannel river networks. Earth Surface Processes and Landforms 38, 1299-1316.

Nicholas A.P., Ashworth P.J., Sambrook Smith G.H., Sandbach S.D. (2013) - Numerical simulation of bar and island morphodynamics in anabranching megarivers. Journal of Geophysical Research: Earth Surface 118, 2019-2044.

Rubin Y., Lunt I.A, Bridge J.S. (2006) - Spatial variability in river sediments and its link with river channel geometry. Water Resources Research 42, W06D16, doi:10.1029/2005WR004853.

Russell A.J., Knudsen Ó. (1999) - Controls on the sedimentology of November 1996 jökulhlaup deposits, Skeiðarársandur, Iceland. In Smith N.D., Rogers, J (Eds.): Fluvial Sedimentology VI. International Association of Sedimentologists Special Publication 28, 315-329.

Russell A.J., Knudsen Ó. (2002a) - The influence of channel flood history on the impact of the November 1996 jökulhlaup, Skeiðarársandur, Iceland. . In Snorasson A., Finnsdóttir H.P., Moss M. (Eds.): The Extremes of the Extremes: Extraordinary Floods. IAHS Publication 271, 243-247.

Russell A.J., Knudsen Ó. (2002b) - The effects of glacier-outburst flood flow dynamics on ice-contact deposits: November 1996 jökulhlaup, Skeiðarársandur, Iceland. In Matini I.P., Baker V.R., Garzón G. (Eds.): Flood and Megaflood Processes and Deposits: Recent and Ancient Examples. International Association of Sedimentologists Special Publication 32, 67-83.

Russell A.J., Duller R.A., Mountney N.P. (2010) - Volcanogenic jökulhlaups (glacier outburst floods) from Mýrdalsjökull: impacts on proglacial environments. In Krüger J., Kjær K.H. (Eds.): The Mýrdalsjökull Ice Cap, Iceland: Glacial Processes, Sediments and Landforms on an Active Volcano. Developments in Quaternary Sciences 13, 181-207.

Russell A.J., Roberts M.J., Fay H., Marren P.M., Cassidy N.J., Tweed F.S., Harris T. (2006) - Icelandic jökulhlaup impacts: Implications for ice-sheet hydrology, sediment transfer and geomorphology. Geomorphology 75 33-64.

Sambrook Smith G.H., Ashworth P.J., Best J.L., Woodward J., Simpson C.J. (2005) - The morphology and facies of sandy braided rivers: some considerations of scale invariance. In Blum M.D., Marriott S.B., Leclair S.F. (Eds.): Fluvial Sedimentology VII. International Association of Sedimentologists Special Publication 35, 145-158.

Sambrook Smith G.H., Ashworth P.J., Best J.L., Woodward J., Simpson C.J. (2006) - The sedimentology and alluvial architecture of the sandy braided South Saskatchewan River, Canada. Sedimentology 53, 413-434.

Sambrook Smith G.H., Best J.L., Ashworth P.J., Lane S.N., Parker N.O., Lunt I.A., Thomas R.E., Simpson C.J. (2010) Can we distinguish flood frequency and magnitude in the sedimentological record of rivers? Geology 38, 579-582.

Sapozhnikov V., Foufoula-Georgiou E. (1996) - Self affinity in braided rivers. Water Resources Research 32, 1429-1439.

Smith L.C., Sheng Y., Magilligan F.J., Smith N.D., Gomez D., Mertes L.A.K., Krabill W.B., Garvin J.B. (2006) - Geomorphic impact and rapid subsequent recovery from the 1996 Skeiðarársandur jökulhlaup, Iceland, measured with multi-year airborne lidar. Geomorphology 75, 65-75.

Snorrason Á., Jónsson P., Sigurðsson O., Pálsson S., Árnason S., Víkingsson S., Kaldal I. (2002) - November 1996 jökulhlaup on Skeiðarásandur outwash plain, Iceland. In Martini I.P., Baker V.R., Garzón G. (Eds.): Flood and Megaflood Processes and Deposits: Recent and Ancient Examples. International Association of Sedimentologists Special Publication 32, 55-65.

Thorne C.R., Russell A.P.G., Alam M.K. (1993) - Planform pattern and channel evolution of the Brahmaputra River, Bangladesh. In Best J.L., Bristow C.S. (Eds.): Braided Rivers. Geological Society Special Publication 75, 257-276.

Warburton J. (1994) - Channel change in relation to meltwater flooding, Bas Glacier d'Arolla, Switzerland. Geomorphology 11, 141-149. 
Wolman M.G., Gerson R. (1978) - Relative scales of time and effectiveness of climate in watershed geomorphology. Earth Surfaces Processes 3, 189-208.

Yalin M.S. (1977) - Mechanics of Sediment Transport. Pergamon, Oxford. (Second Edition), 298 p.

\section{Figure captions}

Fig. 1 - Location of the study site. A: Map of Iceland, the box shows the location of B. B: Map of Skeiðarársandur, the box shows the location of fig. 2.

Fig. 1 - Localisation du site d'étude. A : Carte de l'Islande, l'encadré montre la localisation de B. B : Carte du Skeiðarársandur, l'encadré montre la localisation de la figure 2.

Fig. 2 - Oblique aerial photograph of the Skeiðará river in August 2001, looking upstream from the Skeiðará bridge (foreground). $B, C$ and $D$ identify the location of bars studied in this paper.

Fig. 2 - Photographie aérienne oblique de la rivière Skeiðará en Aout 2001, prise de vue vers l'amont depuis le pont de la Skeiðará (au premier plan). B, C et $D$ localisent les bancs étudiés.

Fig. 3 - Bar deposition during the November 1996 jökulhlaup in the Skeiðará river, based on aerial photography taken on 6 November on the waning stage of the flood. Flow is from north to south. A-D indicate the bars described in this paper. Mapped areas indicate major areas of deposition, including some bars that are partly submerged at the time of photography. Areas mapped as Little Change were inundated, but largely unchanged from pre-flood (1991/1992) photography. The flood lasted for approximately 12 hours after the photography was taken, and further deposition and reworking occurred. 1: 1996 deposition; 2: 1996 little change; $3: 1996$ not flooded; 4: Flood bar outlines; 5: Glacier position 2012; 6; Glacier position 2003; 7: Glacier position 1997; 8: Glacier position 1996; 9: Roads, and flood barriers.

Fig. 3 - Dépôt de banc lors du jökulhlaup de novembre 1996 dans le rivière Skeiðará, sur la base de l'interprétation de la photographie aérienne du 6 novembre durant la phase de décrue. L'écoulement s'effectue du nord vers le sud. A-D indiquent les bancs décrit dans l'article. Les zones cartographiées indiquent les principaux espaces de dépôt, en incluant les bancs qui sont partiellement submergés lors de l'acquisition du cliché. Les zones cartographiées comme "peu changées" ont été submergé mais sont restées quasiment identiques aux photographies antérieures aux jökulhlaups (1991/1992). La crue a perduré approximativement 12 heures après que la photographie a été prise, et des remaniements et des dépôts ont eu lieu. 1 : Dépôt de 1996; 2 : Faible changement en 1996 ; 3 : Zones non affectées par la crue de $1996 ; 4$ : Contours des bancs de crue ; 5 : Position du glacier en $2012 ; 6$ : Position du glacier en 2003; 7 : Position du glacier en 1997; 8 : Position du glacier en 1996; 9 : Routes et digues.

Fig. 4 - Map showing post-flood modification of the November 1996 jökulhlaup deposits from 1997 to 2012 . Flow is from north to south. A-D indicate the bars described in this paper. Changes actually ceased in 2009, when flow into the Skeiðará was diverted into the Gígjukvísl river. Some areas were unchanged from 2003 to 2012, especially in bar B and many areas were repeatedly reworked (reworking is not mapped). 1: Bars 2012; 2: Bars 2003; 3: Bars 1997; 4: 1996 little change; 5: 1996 not flooded; 6: Flood bar outlines; 7: Glacier position 2012; 8; Glacier position 2003; 9: Glacier position 1997; 10: Glacier position 1996; 11: Roads, and flood barriers.

Fig. 4 - Cartographie de l'évolution entre 1997 et 2012 des dépôts du jökulhlaup de 1996. L'écoulement s'effectue du nord vers le sud. A-D indiquent les bancs décrit dans l'article. Les changements morphologiques ont cessé en 2009, lors de la capture de la Skeiðará par la rivière Gígjukvísl. Certaines zones sont restées inchangées entre 2003 et 2012, en particulier sur le banc B, et plusieurs zones ont été remaniées de manière répétée (ces dernières n'ont pas été cartographiées). 1 : Bancs en 2012; 2 : Bancs en 2003; 3 : Bancs en 1997; 4 : Faible changement en 1996 ; 5 : Zones non affectées par la crue de 1996; 6 : Contours des bancs de crue; 7 : Position du glacier en 2012; 8 : Position du glacier en 2003 ; 9 : Position du glacier en 1997; 10 : Position du glacier en 1996; 11 : Routes et digues.

Fig. 5 - Bar dimensions of the unmodified bars B, C and D, and the dimensions of all the individual fragments of bars B, C and D, indicating the trend for bars to become longer and thinner as they are reworked.

Fig. 5 - Dimensions des bancs $\boldsymbol{B}, \boldsymbol{C}$ et $\boldsymbol{D}$ non-modifiés, et dimensions de tous les fragments des bancs $B, C$ et $D$, indiquant la tendance des bancs à devenir de plus en plus longs et étroits au fur et à mesure de leur remaniement.

Fig. 6 - Comparison of the results from this study with the geometric means of the datasets of Sambrook Smith et al. (2005; open squares) and Kelly (2006; open circles). The unmodified Skeiðará bars are shown individually as filled circles whilst the geometric means of the fragments from each bar are plotted as filled triangles.

Fig. 6 - Comparaison des résultats de cette étude avec les moyennes issues des données de Sambrook Smith et al. (2005; carrés blancs) et Kelly (2006 ; cercles blancs). Les bancs non-modifiés de la Skeiðará sont symbolisés individuellement par des cercles noirs tandis que la moyenne de la géométrie des fragments de chacun des bancs sont indiqués par des triangles noirs.

\section{Table captions}

Table. 1. Dimensions of the three major 1996 jökulhlaup bars in the Skeiðará channel

Tab. 1. Dimensions des trois bancs majeurs déposés par le jökulhlaup de 1996 dans le chenal de la Skeiðará. 


\begin{tabular}{l|l|l|l|l|l|l}
\hline & $\begin{array}{l}\text { Bar } \\
\text { length }\end{array}$ & $\begin{array}{l}\text { Bar } \\
\text { width }\end{array}$ & $\begin{array}{l}\text { Channel width } \\
\text { at upstream } \\
\text { pool }\end{array}$ & $\begin{array}{l}\text { Channel width } \\
\text { at widest point } \\
\text { of bar }\end{array}$ & $\begin{array}{l}\text { Bar } \\
\text { L/W } \\
\text { ratio }\end{array}$ & $\begin{array}{l}\text { Channel width } \\
\text { to bar length } \\
\text { scaling factor }\end{array}$ \\
\hline Bar B & 4300 & 2250 & 1300 & 3000 & 1.91 & 3.31 \\
Bar C & 4800 & 2250 & 1500 & 2850 & 2.13 & 3.20 \\
Bar D & 2650 & 1100 & 670 & 1500 & 2.41 & 3.96 \\
\hline
\end{tabular}




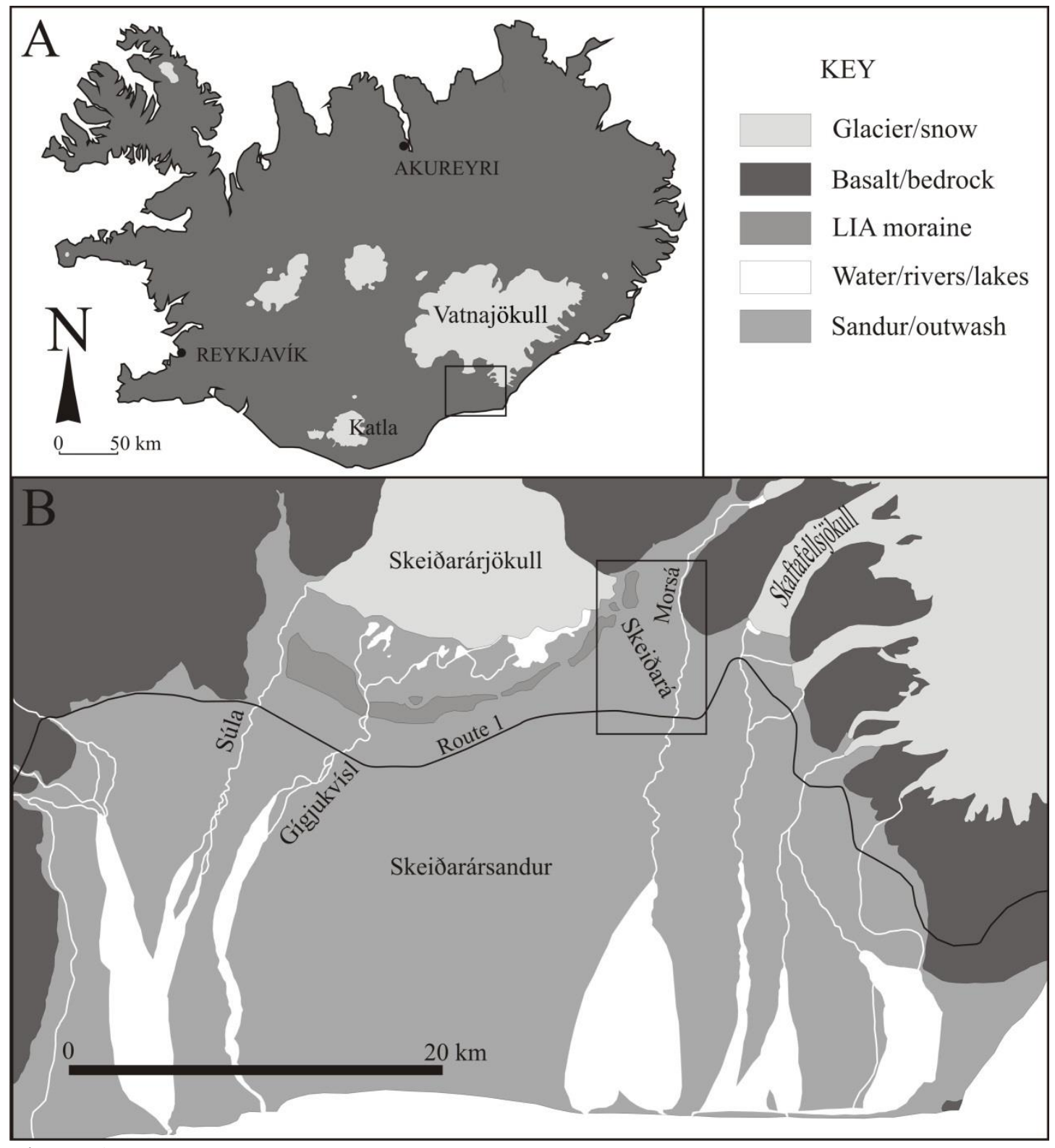

Figure 1. 


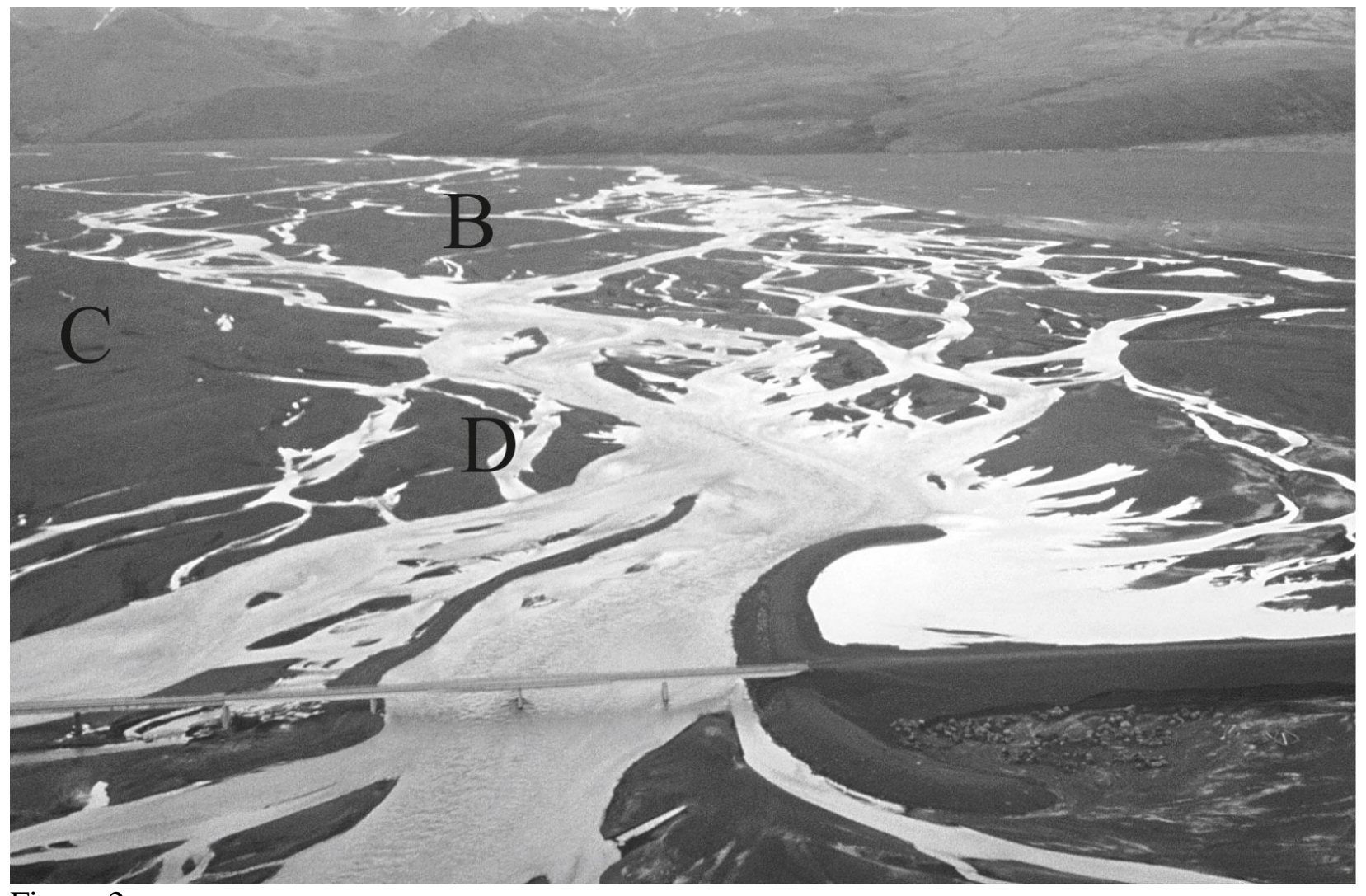

Figure 2. 


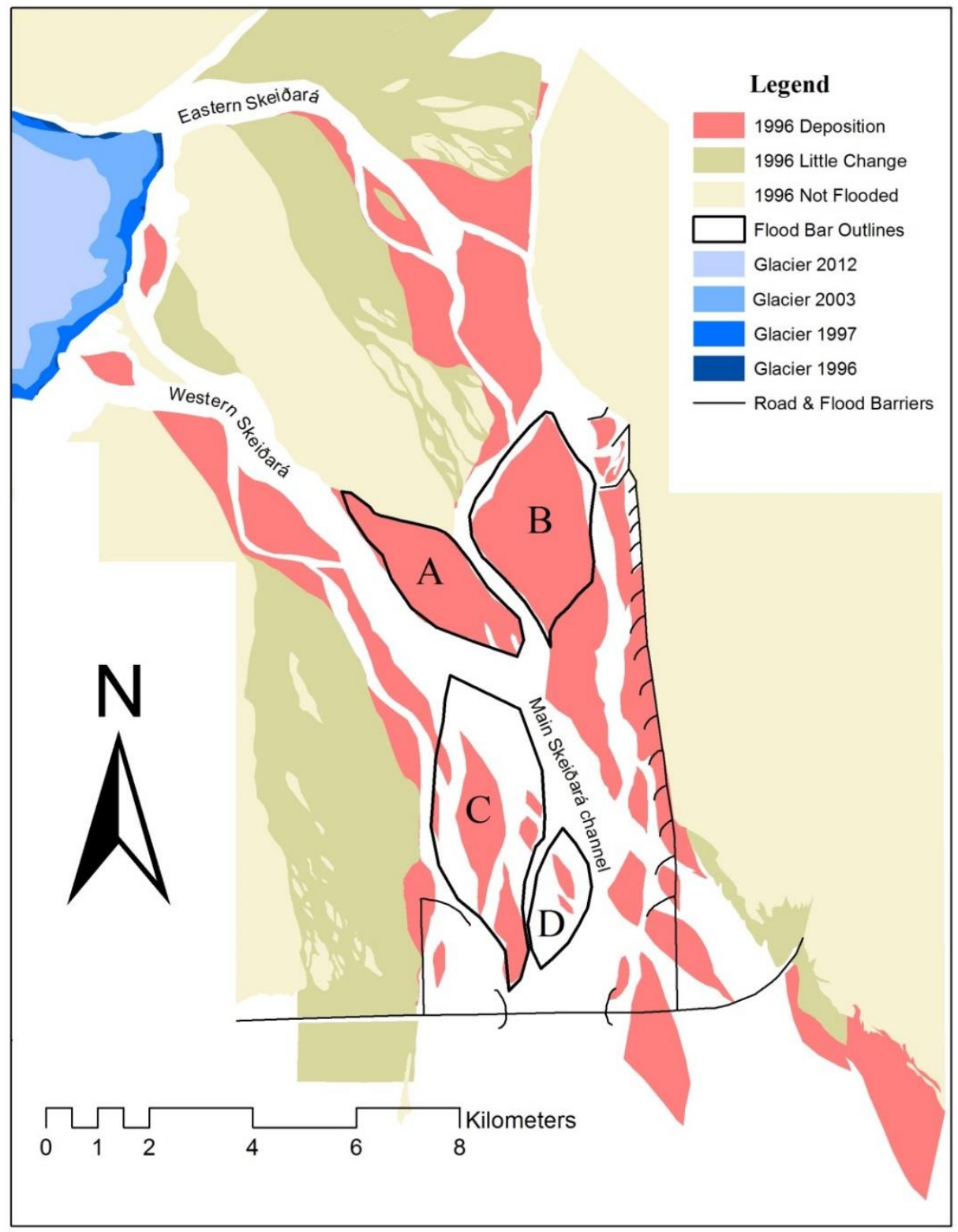

Figure 3. 


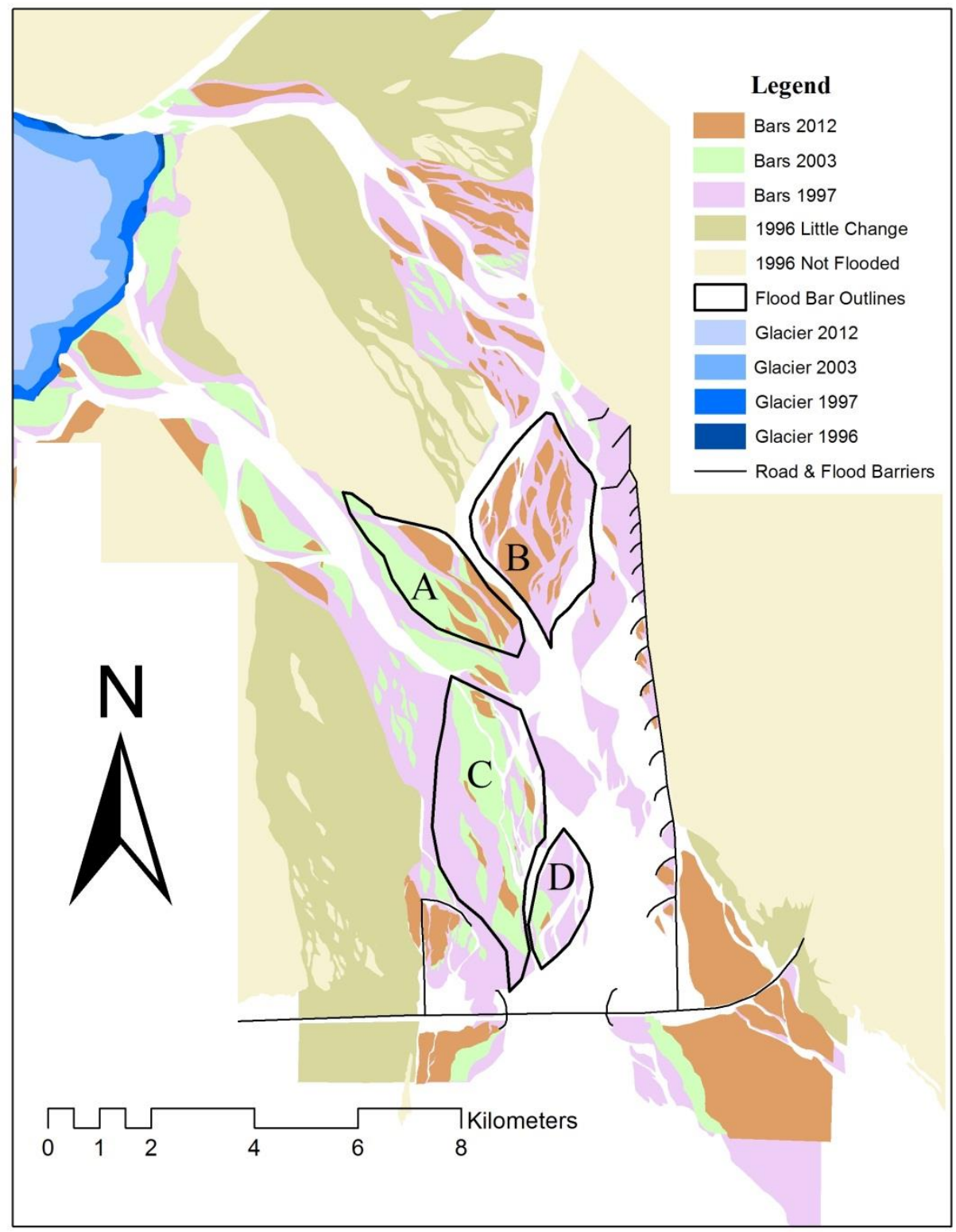

Figure 4. 


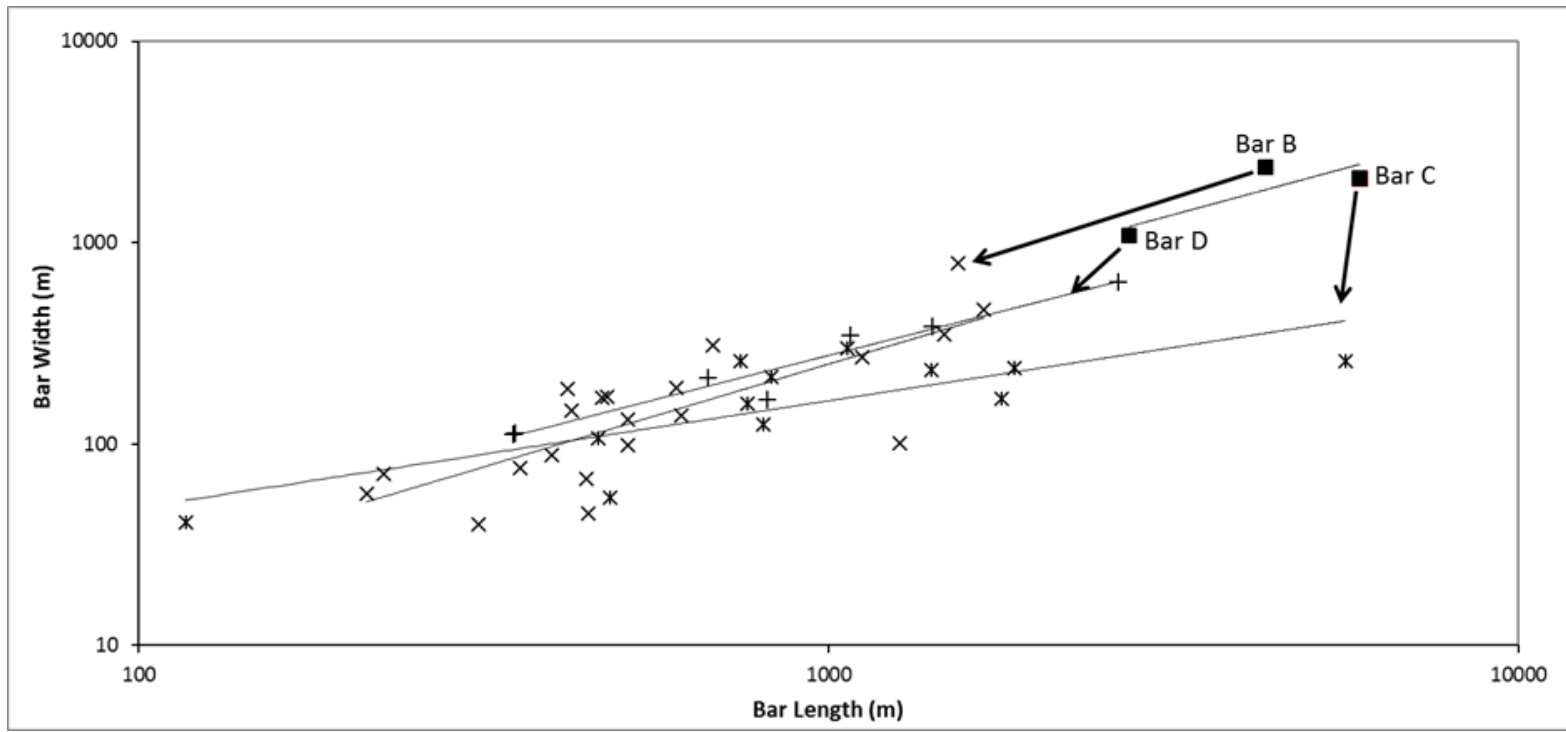

Figure 5. 


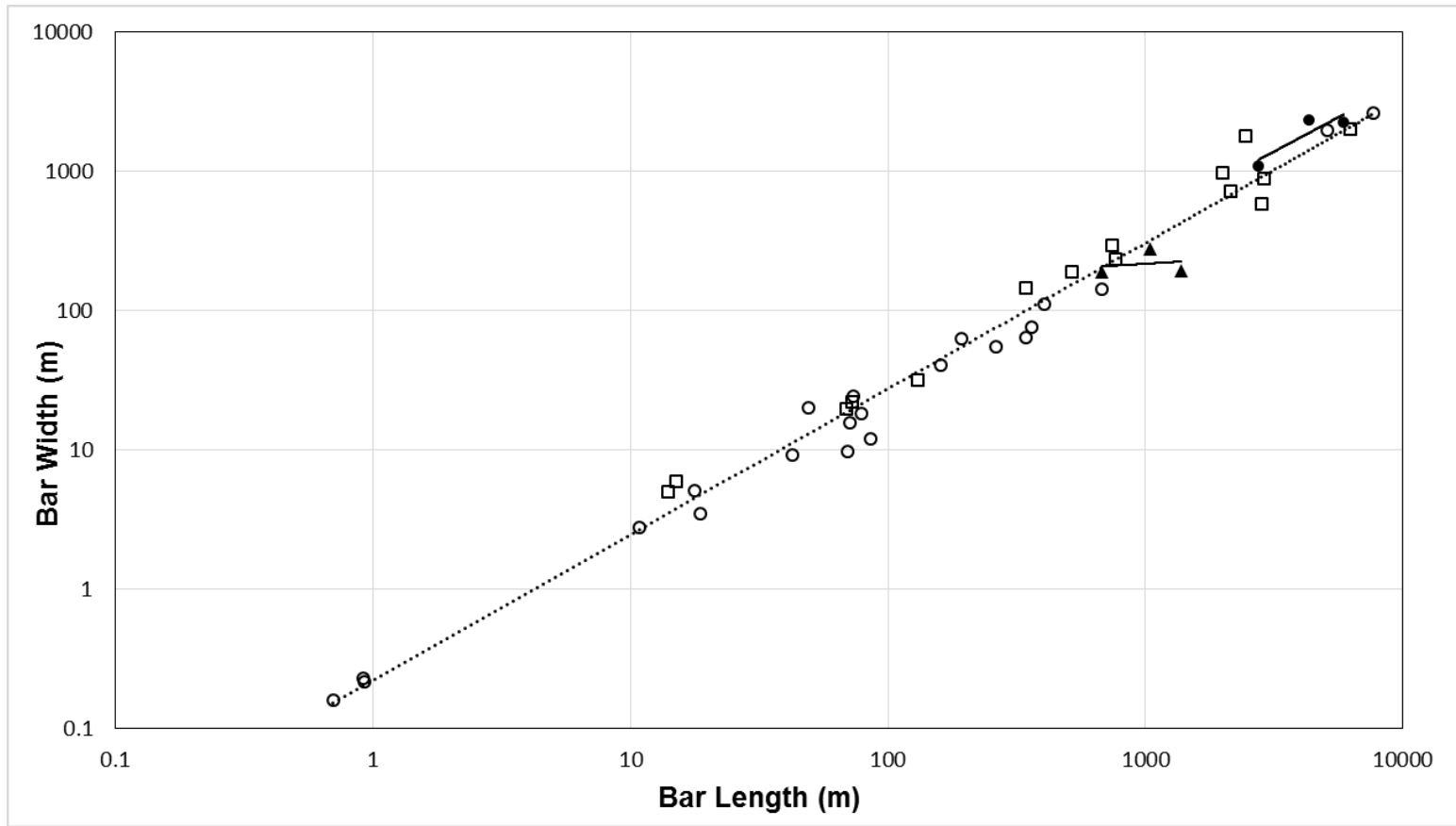

Figure 6. 